\title{
IRRIGATION APPLICATION DEPTHS AND POTASSIUM DOSES ON TOMATOES UNDER PROTECTED ENVIRONMENT IN SOUTHEAST BRAZIL
}

\author{
Jokastah Wanzuu Kalungu ${ }^{1}$, Rodrigo Otávio Câmara Monteiro ${ }^{2}$, Marcos Vinícius Folegatti ${ }^{3}$ \\ ${ }^{1}$ University of Nairobi, Nairobi, Kenya. jwanzuu@ yahoo.com \\ ${ }^{2}$ Instituto Federal de Educação, Ciência e Tecnologia do Rio Grande do Sul- IFRS. Av. Osvaldo Aranha 540 - 95700-000 - \\ Bento Gonçalves - RS, Brasil. rodrigo.monteiro@bento.ifrs.edu.br \\ ${ }^{3}$ Universidade de São Paulo - USP/ESALQ. Caixa Postal 9 - 13418-900 - Piracicaba - SP, Brasil. mvfolega @esalq.usp.br
}

\section{ABSTRACT}

Modern irrigation water and nutrient management strategies improve crop yields and lead to optimum profits. The objective of the study was to evaluate effects of irrigation depths and potassium doses on production, quality and water use efficiency of tomato (Lycopersicon esculentum Mills) under protected environment condition. The treatments consisted of irrigation water levels equivalent to $50,75,100$, and $125 \%$ of crop water requirement (CWR) with potassium doses of 208, 416 and $624 \mathrm{~kg} \mathrm{ha}^{-1}$. A drip irrigation system was used for fertigation of potted Débora Plus tomato variety. Irrigation, potassium doses and its interaction with irrigation levels had significant effects on total, commercial and non commercial production. Marketable yields reached a maximum of $64.4 \mathrm{mg} \mathrm{ha}^{-1}$ at $416 \mathrm{~kg} \mathrm{ha}^{-1}$ of potassium, produced at $75 \% \mathrm{CWR}$. This corresponded to an average irrigation rate of $4.72 \mathrm{~mm}^{-1 a y}{ }^{-1}$. Higher potassium dose of 624 $\mathrm{kg} \mathrm{ha}^{-1}$ depressed total and commercial yields. Tomato fruit $\mathrm{pH}$ values were between 4.0 and 4.5 for all treatments, while the highest total soluble solids were $9.2 \%$, found with irrigation level of $75 \%$ CWR. Maximum water use efficiency was $12.4 \mathrm{~kg} \mathrm{~m}^{-3}$ of applied water, also obtained at $75 \% \mathrm{CWR}$. An irrigation reduction of $25 \% \mathrm{CWR}$ could hence optimize water resources and save significant water quantities through improved efficiency of water applications to the plant.

Keywords: tomato crop, drip irrigation, fertigation, water use efficiency

\section{LÂMINAS DE IRRIGAÇÃO E DOSES DE POTÁSSIO NA PRODUÇÃO DE TOMATE EM AMBIENTE PROTEGIDO NO SUDESTE DO BRASIL}

\section{RESUMO}

A adoção de estratégias modernas de manejo da água e nutrientes possibilitam o aumento da produtividade de culturas agrícolas e a rentabilidade da atividade. O objetivo deste estudo foi avaliar o efeito de lâminas de irrigação e doses de potássio na produção, na qualidade e na eficiência do uso da água (EUA) pelo tomate (Lycopersicon esculentum Mills) variedade Débora Plus em condições protegidas. Os tratamentos consistiram de lâminas de irrigação equivalentes a $50,75,100$ e $125 \%$ da necessidade hídrica da cultura (ETc) com doses de potássio de 208, 416 e $624 \mathrm{~kg} \mathrm{ha}^{-1}$. A irrigação, as doses de potássio e a interação destes fatores influenciaram significativamente a produção total, a comercial e a não comercial. Frutos comerciáveis alcançaram um máximo de $64,4 \mathrm{mg} \mathrm{ha}^{-1}$ para a dose $416 \mathrm{~kg} \mathrm{ha}^{-1}$ de potássio, produzido com a lâmina de $75 \%$ da ETc. Isto correspondeu a uma taxa média de aplicação de 4,72 mm dia ${ }^{-1}$. A maior dose de potássio de $624 \mathrm{~kg} \mathrm{ha}^{-1}$ reduziu a produção total e comercial. Os valores de $\mathrm{pH}$ dos frutos ficaram entre 4,0 e 4,5, enquanto que o valor mais alto de sólidos solúveis totais foi de 
9,2\%, no nível de irrigação de $75 \%$ ETc. A máxima EUA foi de 12,4 $\mathrm{kg} \mathrm{m}^{-3}$, também obtido com $75 \%$ ETc. Uma redução na irrigação em $25 \%$ da ETc pode otimizar e economizar quantidades significativas de água por meio de maior eficiência de aplicação.

Palavras-chave: cultura de tomate, Irrigação por gotejamento, fertirrigação, eficiência do uso da água

\section{INTRODUCTION}

The use of drip irrigation and fertigation for vegetable production has been practiced for many years in developed countries, particularly in the United States, Israel and Germany (Prieto et al., 1999). The system has the potential to apply water both precisely and uniformly at a high irrigation frequency compared with furrow and sprinkler irrigation, resulting in the potential to reduce subsurface drainage, control soil salinity and increase yields (Hanson et al., 2005). Drip irrigation and greenhouse technologies provide and maintain a controlled environment that protect plants from extreme temperatures, rain, winds, hail, insects and diseases, among others. In addition, provision of water and fertilizer at optimum levels leads to the use of low water inputs, high fertilizer efficiencies, and use of less land area for agricultural production.

In Brazil, furrow irrigation is predominant for fresh tomato production. The state of Sao Paulo produces $21 \%$ of the national annual production of fresh tomato with an average production of $58 \mathrm{mg} \mathrm{ha}^{-1}$ (FNP, 2006). Due to economic and environmental reasons such as the need for higher yields and decreasing sources of irrigation water, drip irrigation becomes a viable alternative, especially for valuable crops like tomatoes. Presently, drip irrigated fresh tomatoes are grown on about 450 ha while about 1300 ha is on processing tomatoes (Marouelli and Silva, 2007). Adoption of drip irrigation has been slow due to its high initial installation cost and lack of technical services compared to other irrigation systems (Hanson et al., 2005).
Increased use of drip irrigation can be facilitated by addressing irrigation management issues, especially in greenhouse conditions, with the aim of improving competitiveness and expansion of acreage in the country. This will ensure efficient use of fertilizers, water and other inputs essential for sustainable food production as well as environmental conservation.

Tomato fruit constitutes an important source of minerals, vitamins, and powerful antioxidant compounds. Due to its importance, there is increasing effort to improve its production in terms of quality and quantity. Nitrogen and potassium are fundamental in achieving high marketable yields while phosphorus is essential for early growth and root development. However, tomato crop has a relatively high potassium requirement given that it is needed throughout the season (Harmoto et al., 2004). The specific objective was to evaluate effects of irrigation levels and potassium doses on production, fruit quality and water use efficiency of a tomato cultivar, Debora Plus, grown in a protected environment.

\section{MATERIAL AND METHODS}

The study was set up at the Biosystem Engineering Department, "Escola Superior de Agricultura Luiz de Queiroz, (ESALQ)", in Piracicaba, Sao Paulo State, Brazil, located at latitude $22^{\circ} 42^{\prime} 00^{\prime \prime}$ South and longitude $47^{\circ} 38^{\prime} 00^{\prime \prime}$ West, at an elevation of $520 \mathrm{~m}$ above sea level.

Tomato variety Debora Plus was selected due to its long life, disease resistance, high yielding and be popularly grown in the area. Seeds were sowed in the 
nursery for 34 days before transplanting them to a naturally ventilated greenhouse in June 2007. The greenhouse was $17.3 \mathrm{~m}$ long and $6.4 \mathrm{~m}$ wide; it was covered with a low density transparent polyethylene film of 3.0 $\mathrm{m}$ high and $0.01 \mathrm{~mm}$ thickness. The seedlings were grown in plant pots $0.21 \mathrm{~m}^{3}$ volume and surface area of $0.71 \mathrm{~m}^{2}$, spaced at $0.5 \mathrm{~m}$ by $1 \mathrm{~m}$ inter and line spacing, respectively. The soil was classified as sandy loam and its bulk density was $1.45 \mathrm{~g} \mathrm{~cm}^{-3}$.

A drip irrigation system supplied water to the potted plants. It consisted of drip lines fitted with two pressure-compensating emitters per plant with a total discharge rate of $4 \mathrm{~L} \mathrm{~h}^{-1}$. The emitters were placed about 5 $\mathrm{cm}$ from the tomato stem on opposite sides. The lateral lines consisted of polyethylene tubes of $13 \mathrm{~mm}$ diameter, spaced at $1 \mathrm{~m}$ apart. The pressure system consisted of a pump driven by a $0.5 \mathrm{cv}$ electrical motor, with manometer and flow meters placed on the mainline. Irrigation applications were automated using valves which were activated through a data logger installed in the greenhouse. Air temperature and relative humidity inside and outside the greenhouse were measured by use of thermocouple sensors connected to a data logger programmed to record data at each 15 minutes interval.

The experimental design was complete random design. It consisted of four irrigation levels and three potassium doses, with three replications. The arranged factorial scheme of $4 \times 3$ hence resulted to 36 plots. The four irrigation levels were 50, 75, 100 and $125 \%$ of crop water requirements (CWR), denoted as I1, I2, I3 and I4, respectively. The three potassium treatments applied were 208, 416 and $624 \mathrm{~kg}$ of $\mathrm{K}_{2} \mathrm{O}$ per hectare, denoted as $\mathrm{K} 1, \mathrm{~K} 2$ and $\mathrm{K} 3$, respectively. These were equivalent to $10.4,20.8,31.2 \mathrm{~g}$ plant $^{-1}$ cycle $^{-}$ 1 , applied by fertigation according to recommendations of Alvarenga (2004) for tomato crop with specification of the grown variety. A total of 130 plant pots were used in this study, with the row on the border of the plot giving a buffer zone of 58 plants.

All plants were uniformly irrigated for 11 days after transplanting where the top $0.20 \mathrm{~m}$ soil was pre-irrigated to near field capacity to minimize effect of different irrigation levels. All treatments were also pre-fertigated with $144 \mathrm{~kg}$ of nitrogen, 434 $\mathrm{kg}$ of $\mathrm{P}_{2} \mathrm{O}_{5}, 72 \mathrm{~kg}$ of calcium, $28 \mathrm{~kg}$ of magnesium, $4 \mathrm{~kg}$ of zinc and $1.4 \mathrm{~kg}$ of boron per hectare. Fertilizer sources included potassium and calcium nitrate, magnesium and zinc sulfate as well as borax. Subsequent irrigations and potassium fertilizer doses were then applied according to treatments.

The amount of irrigation water applied to the potted plants was estimated by using an adjusted formula of Van Genuchten (1980) as shown in Equation 1.

$\theta(\Psi \mathrm{m})=0.087-0.407 /[1+(0.1556 \times \Psi \mathrm{m}) 1.1389] 0.7785$

Where $\theta$ was actual soil water content $\left(\mathrm{cm}^{3}\right.$ $\mathrm{cm}^{-3}$ ) and $\Psi \mathrm{m}$ was the soil matric potential (m). Soil water moisture was controlled through tensiometers by keeping the water tension between $10-15 \mathrm{kPa}$.

Pruning of the tomatoes was carried out twice a week to maintain a uniform growth while staking was done at 15 days after transplanting (DAT). Pest management was carried out as required. Harvesting was done manually from 75 to 140 DAT.

Total tomato fruits produced were weighed using a precision balance to provide yields. Quality of tomatoes was quantified by $\mathrm{pH}$ and total soluble solids using standard laboratory methods on a cluster of six tomatoes per treatment. Water use efficiency (WUE in $\mathrm{Kg} \mathrm{m}^{-3}$ ) was expressed by Equation 2.

$$
\mathrm{WUE}=\mathrm{Ey} / \mathrm{ETc}
$$

Where Ey was economic yields expressed as total fresh fruit weight $(\mathrm{Kg})$ and ETc was crop water use, expressed as volume of 
irrigation water applied $\left(\mathrm{m}^{3}\right)$ per treatment. Monitoring of soil salinity and soil $\mathrm{pH}$ levels were carried out weekly from saturation extracts obtained at $0.15 \mathrm{~m}$ depth.

The effect of irrigation water levels and potassium doses were then compared through a one-way analysis of variance (ANOVA) using the SAS system (PROC GLM, SAS Institute, 1998), while means were compared using the Duncan Multiple Range Test (DMRT).

\section{RESULTS AND DISCUSSION}

The maximum temperature attained inside the greenhouse was $45.6{ }^{\circ} \mathrm{C}$ with mean daily temperature of $34.5{ }^{\circ} \mathrm{C}$. The recommended optimum mean daily temperature for tomato production is between 18 to $25{ }^{\circ} \mathrm{C} \quad$ (FAO, 2002). According to Calvert (1969), high temperatures induce flower abortion hence the observed high temperatures could affect physiological development and cause reduced yields of the tomato crop.

Maximum relative humidity inside the greenhouse was about $100 \%$ while the minimum was about $10 \%$ throughout the study period. This indicated that the greenhouse controlled and maintained the environment for crop production. However, minimum relative humidity outside the greenhouse indicated large fluctuations, ranging from $100 \%$ to about $20 \%$ during the season. The study period included the last three months of winter.

Table 1 presents the total amount of water applied to each treatment during the study period between June and October, 2007. The treatment with $100 \%$ CWR (I3) received 72.5 litres of water during the crop season. Similarly, 50, 75 and 125\% CWR received 36.2, 54.4, and 90.6 litres, respectively.

Irrigation water levels, potassium doses and their interactions indicated a significant effect on total, commercial and non commercial production at $5 \%$ significance level (Table 2). At 50\% CWR, there was marked disparity between total, commercial and non commercial yields. This was due to a large percentage of small, unmarketable tomato fruits with a diameter less than $40 \mathrm{~mm}$ which reduced growers' profits. This was attributed to low soil moisture in the root zone that resulted in water stress to plant growth. This led to about $70 \%$ yield reduction compared to maximum total yields.

At irrigation levels of 50, 75 and $100 \%$ CWR, the higher potassium dose of $624 \mathrm{~kg}$ $\mathrm{ha}^{-1}$ depressed total and commercial yields. In the higher irrigation level of $125 \% \mathrm{CWR}$, total and commercial yields responded positively to potassium applications up to $624 \mathrm{~kg} \mathrm{ha}^{-1}$ with $15 \%$ yield increase.

Table 1. Total volume of irrigation water applied to tomato crop

\begin{tabular}{lcccc}
\hline \multirow{2}{*}{ Period } & \multicolumn{4}{c}{ Treatments - irrigation levels $\left(\mathbf{L}\right.$ plant $\left.^{\mathbf{- 1}}\right)$} \\
& $\mathbf{I 1}$ & $\mathbf{I 2}$ & $\mathbf{I 3}$ & $\mathbf{I 4}$ \\
\hline June & 0.38 & 0.57 & 0.76 & 0.95 \\
July & 4.17 & 6.25 & 8.34 & 10.40 \\
August & 16.13 & 24.20 & 32.27 & 40.33 \\
September & 15.01 & 22.52 & 30.03 & 37.53 \\
October & 0.54 & 0.82 & 1.09 & 1.360 \\
\hline Total $\left(\mathbf{L ~ p l a n t ~}^{-\mathbf{1}}\right)$ & 36.24 & 54.36 & 72.48 & 90.60 \\
\hline
\end{tabular}

I1, I2, I3 and I4 - irrigation levels 50, 75, 100, and 125\% of crop water requirement, respectively 
Table 2. Total, commercial and non-commercial tomato yields $\left(\mathrm{mg} \mathrm{ha}^{-1}\right)$ as a function of irrigation levels and potassium doses.

\begin{tabular}{ccccc}
\hline \multicolumn{2}{c}{ Treatments } & \multicolumn{3}{c}{ Tomato yields $\left(\mathbf{m g ~ h a}^{-\mathbf{1}}\right)$} \\
\hline $\begin{array}{c}\text { Irrigation } \\
(\% \text { CWR })\end{array}$ & $\begin{array}{c}\text { Potassium } \\
\text { doses } \\
\left(\mathbf{k g ~ h a}^{-1}\right)\end{array}$ & Total & Commercial & Non-commercial \\
\hline 50 & 208 & $21.3 \pm 2.02 \mathrm{e}$ & 0 & $21.27 \pm 0.86 \mathrm{a}$ \\
& 416 & $21.8 \pm 1.47 \mathrm{e}$ & 0 & $21.83 \pm 1.50 \mathrm{a}$ \\
75 & 624 & $19.4 \pm 3.30 \mathrm{e}$ & 0 & $22.43 \pm 0.78 \mathrm{a}$ \\
& 208 & $38.4 \pm 0.72 \mathrm{~d}$ & $36.23 \pm 4.75 \mathrm{bcd}$ & $2.6 \pm 0.20 \mathrm{~d}$ \\
& 416 & $64.4 \pm 0.6 \mathrm{~b}$ & $54.2 \pm 2.23 \mathrm{~b}$ & $10.0 \pm 0.32 \mathrm{c}$ \\
& 624 & $41.8 \pm 1.57 \mathrm{~cd}$ & $28.17 \pm 2.22 \mathrm{~d}$ & $13.83 \pm 1.04 \mathrm{~b}$ \\
& 208 & $42.4 \pm 3.00 \mathrm{~cd}$ & $30.2 \pm 3.23 \mathrm{~cd}$ & $11.87 \pm 0.82 \mathrm{bc}$ \\
& 416 & $62.4 \pm 1.92 \mathrm{~b}$ & $52.27 \pm 4.38 \mathrm{a}$ & $12.36 \pm 0.40 \mathrm{c}$ \\
& 624 & $49.9 \pm 4.98 \mathrm{c}$ & $29.93 \pm 5.23 \mathrm{~cd}$ & $19.98 \pm 0.01 \mathrm{a}$ \\
& 208 & $46.6 \pm 3.40 \mathrm{~cd}$ & $34.83 \pm 3.16 \mathrm{bcd}$ & $11.83 \pm 0.12 \mathrm{bc}$ \\
& 416 & $50.9 \pm 3.77 \mathrm{c}$ & $40.77 \pm 2.86 \mathrm{~b}$ & $10.83 \pm 1.24 \mathrm{c}$ \\
& 624 & $59.9 \pm 4.73 \mathrm{~b}$ & $39.17 \pm 0.17 \mathrm{bc}$ & $20.87 \pm 0.55 \mathrm{a}$ \\
\hline
\end{tabular}

Means with the same letters within a column are not significantly different from each other at 0.05 level (DMRT)

The reason for the different responses to the potassium doses between the 50 and $125 \%$ CWR irrigation levels was attributed to potassium losses due to leaching. It was also noted that the higher irrigation level of $125 \%$ CWR did not result in maximum total yields. This was because the high irrigation amount caused a very humid region in the root zone that reduced oxygen diffusion into the root zone; such an environment inhibits plant growth and production (Pezeshki, 1994).

Marketable tomato yields reached a maximum of $64.4 \mathrm{mg} \mathrm{ha}^{-1}$ at $416 \mathrm{~kg} \mathrm{ha}^{-1}$ of potassium, produced at $75 \% \mathrm{CWR}$ irrigation level. However, this yield was not significantly different from yield of $62.4 \mathrm{mg}$ $\mathrm{ha}^{-1}$ obtained with irrigation level of $100 \%$ CWR with potassium dose of $416 \mathrm{~kg} \mathrm{ha}^{-1}$. Tomato crop hence showed good osmotic adjustment and drought resistance at $75 \%$ CWR irrigation level. The optimum water requirement for greenhouse tomato crop, variety Debora Plus was hence found to be at $75 \%$ CWR irrigation level. This corresponded to an average irrigation rate of $4.72 \mathrm{~mm} \mathrm{day}^{-1}$ or $0.59 \mathrm{~L}_{\text {plant }}{ }^{-1}$ day ${ }^{-1}$, which was consistent with Harmoto et al. (2004) who reported a value between 4.1 and $5.6 \mathrm{~mm}$ day $^{-1}$.

The total yield of $64.4 \mathrm{mg} \mathrm{ha}{ }^{-1}$ obtained in this study higher when compared to the national average of $56.2 \mathrm{mg} \mathrm{ha}^{-1}$ (IBGE, 2006). However, it was lower compared to total yields of $97.9 \mathrm{mg} \mathrm{ha}^{-1}$ reported by Macêdo and Alvarenga (2005). These lower yields were attributed to effects of high temperatures during the growing period, which led to abortion of flowers and to blotchy ripening, resulting to noncommercial fruits. Crop water requirements can be influenced by microclimatic parameters, crop variety, location and season. 
Table 3 presents chemical characteristics of tomato crop as a function of irrigation levels and potassium doses. Irrigation levels had significant effects on crop quality at 5\% level both for $\mathrm{pH}$ and soluble solids. The $\mathrm{pH}$ values were between 4.0 and 4.5 for all treatments, which were similar to values reported by Sapers et al. (1978) for tomato varieties which were between 3.9 and 4.9 .

Increased irrigation levels led to a decrease in soluble solids. Potassium doses and its interaction with irrigation levels did not have any effect on $\mathrm{pH}$ nor on soluble solids. This was supported by Sampaio and Fontes (1998) who reported no significant effects of total soluble solids on fresh tomato fertigated with various doses of potassium. The highest total soluble solids were $9.2 \%$, found with irrigation level of $75 \%$ CWR and at $208 \mathrm{~kg} \mathrm{ha}^{-1}$ of potassium doses. This was contrary to the expectation that high potassium doses should result into high soluble solids.
Water Use Efficiency (WUE) represents the productivity of irrigation water related to yields. WUE presents different trends for the three potassium doses. It was showed a quadratic response of average total yields to irrigation levels at potassium dose of $208 \mathrm{Kg} \mathrm{ha}^{-1}$. WUE was a maximum of $6.0 \mathrm{~kg} \mathrm{~m}^{-3}$ at irrigation level of $75 \%$ CWR, given by a crop yield of about $38.4 \mathrm{mg} \mathrm{ha}^{-1}$.

Regarding to $416 \mathrm{~kg} \mathrm{ha}^{-1}$ of potassium dose also indicated a quadratic response of average total yields against irrigation levels. Maximum WUE was $12.4 \mathrm{~kg} \mathrm{~m}^{-3}$ obtained at $75 \% \mathrm{CWR}$ at total yields of $64.4 \mathrm{mg} \mathrm{ha}^{-1}$. This value was higher than $10.5 \mathrm{~kg} \mathrm{~m}^{-3}$ reported by Soares and Faria (1983); it was also higher than the recommended range of 10-12 $\mathrm{kg} \mathrm{m}^{-3}$ cited by FAO (2002). However, for potassium dose of $624 \mathrm{~kg} \mathrm{ha}^{-1}$, there was a linear increase of yields with increase in irrigation levels. The yield increased from $19.4 \mathrm{mg} \mathrm{ha}^{-1}$ at irrigation level of $50 \%$ CWR to $59.9 \mathrm{mg} \mathrm{ha}^{-1}$ at irrigation level of $125 \%$ CWR.

Table 3. Chemical characteristics of tomato crop as a function of irrigation levels and potassium doses

\begin{tabular}{cccc}
\hline $\begin{array}{c}\text { Treatments Irrigation } \\
(\% \mathbf{C W R})\end{array}$ & $\begin{array}{c}\text { Potassium doses } \\
\left(\mathbf{k g ~ h a}^{-\mathbf{1}}\right)\end{array}$ & $\mathbf{p H}$ & $\begin{array}{c}\text { Total soluble solids } \\
(\boldsymbol{\%})\end{array}$ \\
\hline 50 & 208 & $4.01 \pm 01 \mathrm{~d}$ & $8.7 \pm 0.09 \mathrm{bc}$ \\
& 416 & $4.090 \pm 01 \mathrm{~d}$ & $9.1 \pm 0.09 \mathrm{~d}$ \\
& 624 & $4.090 \pm 06 \mathrm{~d}$ & $8.9 \pm 0.06 \mathrm{~b}$ \\
75 & 208 & $4.37 \pm 02 \mathrm{bc}$ & $9.2 \pm 0.40 \mathrm{a}$ \\
& 416 & $4.5 \pm 0.60 \mathrm{c}$ & $9.1 \pm 0.10 \mathrm{a}$ \\
& 624 & $4.38 \pm 0.40 \mathrm{bc}$ & $8.8 \pm 0.10 \mathrm{a}$ \\
& 208 & $4.49 \pm 0.01 \mathrm{a}$ & $8.7 \pm 0.09 \mathrm{ab}$ \\
& 416 & $4.43 \pm 0.01 \mathrm{ab}$ & $8.5 \pm 0.11 \mathrm{ab}$ \\
& 624 & $4.45 \pm 0.03 \mathrm{ab}$ & $8.8 \pm 0.06 \mathrm{a}$ \\
& 208 & $4.03 \pm 0.01 \mathrm{~d}$ & $7.5 \pm 0.06 \mathrm{c}$ \\
& 416 & $4.06 \pm 0.05 \mathrm{~d}$ & $7.2 \pm 0.06 \mathrm{c}$ \\
& 624 & $4.04 \pm 01 \mathrm{~d}$ & $7.4 \pm 0.07 \mathrm{c}$ \\
\hline Means with the same letters within a column are not significantly different from each other at 0.05 level (DMRT)
\end{tabular}


Apart from potassium dose of $624 \mathrm{~kg}$ $\mathrm{ha}^{-1}$, WUE decreased with increase of irrigation water levels at $100 \% \mathrm{CWR}$ and $125 \%$ CWR. These observations were also supported by Tuzel et al., (1994) and Warner (2004). The factorial treatment with irrigation level of $75 \% \mathrm{CWR}$ and potassium dose of $416 \mathrm{~kg} \mathrm{ha}^{-1}$ was found to be the best treatment in terms of water productivity, which resulted in a WUE of $12.4 \mathrm{~kg} \mathrm{~m}^{-3}$. The least was treatment with $50 \% \mathrm{CWR}$ and potassium dose of $624 \mathrm{~kg} \mathrm{ha}^{-1}$, where WUE was about $4.0 \mathrm{~kg} \mathrm{~m}^{-3}$. The observation that plants use water more effectively at lower irrigation levels than at higher amounts was also reported by Sezen (2006) for similar treatments.

The 50\% CWR irrigation water level indicated electrical conductivity (ECe) values of $4.4,4.8$ and $8.11 \mathrm{dSm}^{-1}$ for potassium doses of 208, 416 and $624 \mathrm{~kg} \mathrm{ha}^{-1}$, respectively. According to Maas and Hoffman (1977), tomato crop is moderately sensitive to salinity. The maximum soil salinity tolerated by tomato crop is based on ECe of $2.5 \mathrm{dSm}^{-1}$. Above this soil salinity level, there is a reduction of $9.9 \%$ in yields for each unit increase of salinity.

The high ECe values associated with $50 \%$ CWR were attributed to low quantity of applied water that could not leach excess salts, especially the $\mathrm{K}^{+}$and $\mathrm{NH}_{4}{ }^{+}$, since potassium nitrate was used for the treatments. This explains the observed low yields and low WUE for treatment with 50\% CWR at potassium dose of $624 \mathrm{~kg} \mathrm{ha}^{-1}$. There was a $35 \%$ reduction in yields for the same treatment with increased electrical conductivity.

However, irrigation level of $125 \%$ CWR for the same potassium doses indicated ECe of 1.8, 2.06 and $3.4 \mathrm{dSm}^{-1}$, respectively. This higher irrigation application had leaching effects in the root zone, hence there was low salt accumulation. Though this treatment did not result to highest yields, the leaching effect resulted in the observed increase of yields with increased potassium doses.

\section{CONCLUSIONS}

These results indicated that an irrigation reduction of $25 \% \mathrm{CWR}$ and application $416 \mathrm{~kg} \mathrm{ha}^{-1}$ of potassium could hence optimize water and nutrient use resources and save significant water and costs through improved efficiency of water and fertilizers applications to the plant.

\section{REFERENCES}

ALVARENGA, M. A. R. 2004. Tomate, produção em campo, em casa de vegetaçao e em hidroponia. Lavras: Universidade Federal de Lavras, 47p.

CALVERT, A. 1969. Studies on the postinitiation development of lower buds of tomato (Lycopersicon esculentum). HortScience, v.44, p.17-126.

FNP. 2006. Tomate. São Paulo, p.476-482 (Anuário da Agricultura Brasileira).

FAO. 2002. Tomato water management. Rome: Crop Description and Climate, Available at: http://www.fao.org/ag/AGL/AGLW/c ropwater/default.stm. Access: Apr. 22, 2010.

HANSON, B. R.; HUTMACHER, R. B.; DONALD, M. M. 2005. Drip irrigation of tomato and cotton under shallow saline ground water conditions. Journal of Irrigation Drainage Systems. v.20, p.155-175.

HARMOTO; SALOKHEA, V. M; BABELB, M. S.; TANTAUC, H. J. 2004. Water requirement of drip irrigated tomatoes grown in greenhouse in tropical environment. Journal Agricultural Water Management, v.71, p.225-247.

IBGE. 2006. Levantamento sistemático da produção agrícola. Available at: 
<http://www.sidra.ibge.gov.br/bda/acerv o>. Access: Apr. 02, 2010.

MAAS, E. V.; HOFFMAN, G. J. 1977. Crop salt tolerance. Journal of Irrigation Drainage Systems. v.103, p.115-134. MACÊDO, L. S.; ALVARENGA, M.A.R. 2005. Effects of water nivels and potassium fertigation on growth, production and quality of tomato fruits in greenhouse. Ciência e Agrotecnologia, v.29, p.296-304.

MAROUELLI, W. A.; SILVA, W. L. C. 2007. Water tension thresholds for processing tomatoes under drip irrigation in Central Brazil. Journal of Irrigation Science, v.25, p.411-417.

PEZESHKI, S. R. 1994. Plant responses to flooding. In: Wilkinson, R.E. (ed). Plant environment interactions. New York: Marcel Dekker Inc, p. 289-312.

PRIETO, M. H.; LÓPEZ, J.; BALLESTEROS, R. 1999. Influence of irrigation system and strategy of the agronomic and quality parameters of the processing tomatoes, Acta Horticulturae, v.487, p.575-579.

SAMPAIO, R. A.; FONTES, P. C. R. 1998. Qualidade de frutos de tomateiro fertirrigado com potássio no solo coberto com polietileno preto. Horticultura Brasileira, v.6, p.136139.

SAPERS, G. M; PHILLIPS, J. G; PANASIUK, O.; CARRÉ, J.; STONER, A. K.; BARKSDALE, T. 1978. Factors affecting the acidity of tomatoes. Hortscience, v.13, p.87-89.

SAS INSTITUTE. 1998. User's Manual, Version 7.0. SAS Institute, Cary, NC.

SEZEN, S. M. 2006. Effects of drip irrigation management and different soilless culture on yield and quality o tomato grown in a plastic house, Pakistan Journal of Biological Science, v.9, p 767-768.

SOARES, J. M.; FARIA, M. B. 1983. Métodos de irrigação e adubação na cultura do tomate industrial. Pesquisa Agropecuária Brasileira, v.18, p.281286.

TÜZEL, Y.; UL, M. A.; TÜZEL, I. H. 1994. Effect of different irrigation intervals and rates on spring season glasshouse tomato production: II Fruit quality. Acta Horticulturae, v.366, p.389-396.

VAN GENUCHTEN, M. T. 1980. A closedform equation for predicting the hydraulic conductivity of unsaturated soils. Journal of America Soil Science Society, v.44, p.892-898.

WARNER, J. 2004. Effect of regulated deficit drip irrigation on processing tomato fruit solids and yield. American Society Agricultural of Biological Engineering., p. 4-6. 